\title{
PRIZVUCI METAFIZIČKE POEZIJE U ROMANU MOBI DIK HERMANA MELVILA
}

U radu se ispituju i pronalaze sličnosti u stvaralaštvu engleskih metafizičkih pesnika XVII veka i romana Hermana Melvila Mobi Dik, pre svega na osnovu teorije intertekstualnog čitanja, odnosno ideje Julije Kristeve da se književna dela odlikuju pluralizmom značenja, koji je nastao usled neizbežnog i neprestanog dijaloga koji se odvija između književnih tekstova. Autorka rada navodi visprenost, dovitljivost i domišljatost književnog izraza kao zajedničke karakteristike metafizičke poezije i Melvilovog narativa o prkosnom osvetniku Ahavu koji beskompromisno lovi belog kita, svog najvećeg neprijatelja na Zemlji. Pored zajedničkih motiva, prepoznaje se i upotreba sličnih književnih sredstava kao što su biblijske aluzije i alegorije. Prožimanje motiva, stilskih figura i filozofsko-književnih ideja upućuje na intertekstualnu povezanost metafizičkih stihova i Melvilove poetike.

Ključne reči: Herman Melvil, Mobi Dik, intertekstualnost, engleska metafizička poezija, končeto.

\section{UvoD}

Kada je davne 1985. godine Umberto Eko objavio „Napomene uz Ime ruže”, otkrio je „ono što su pisci oduvek znali (i toliko nam puta kazali): knjige uvek govore o drugim knjigama, a svaka priča pripoveda već ispričanu priču" (Еко 1985). Time on nije književnost označio kao puko mimetičko stvaralaštvo, nego je ukazao na bezbrojne i raznovrsne relacije koje se mogu pronaći između književnih dela. 
Roman Mobi Dik (Moby Dick, 1851) na najbolji način pokazuje kako jedan pisac, koristeći jezik, motive, čak redosled kazivanja svojih književnih prethodnika, može uspešno da razradi izuzetno originalan zaplet. Zanimljiv je podatak da je Herman Melvil (Herman Melville) skoro sve važne knjige pročitao obrnutim redom od većine pisaca - čitanje nije prethodilo njegovom životnom iskustvu, već ga je sledilo. Melvil nije čitao knjige u sklopu formalnog obrazovanja, jer je nakon očeve smrti morao da prekine školovanje zbog novčanih problema. Postao je mornar na trgovačkom brodu, tako da je samo kitarica bila njegov Jejl i Harvard (MaTHIESSEN 1941: 121-122).

Melvila su odgajili pobožni roditelji pod uticajem reformacijske dogme Žana Kalvina. Naučili su sina da veruje da je božjom voljom predodređen za prokletstvo večitog pakla, ali da, zahvaljujući božjoj milosti, postoji mogućnost izbavljenja. Odnosno, ako se pokorno i bespogovorno preda volji boga spasitelja, u nekom vanzemaljskom životu sledi nagrada. Izgleda da je Melvil verovao u istinitost ovog učenja do osamnaeste godine, dok nije napustio roditeljski dom. Kada je, na prvom putovanju brodom, doživeo duboko razočaranje, sve iluzije su se raspršile. Melvil je tada podigao glas protiv kalvinističkog nasleđa pišući prve romane Tajpi, Omo i Mardi. Njegovu veru u kalvinističkog boga poljuljale su sumnja i skepsa. Duboko je verovao da primarna briga svevišnjeg ne bi trebalo da bude da zahteva strogu poslušnost, nego da kažnjava zlo. Uveren da previše zlodela prolazi nekažnjeno, Melvil dolazi do spoznaje da je bog izvor odakle potiče zlo, jer se sveti onima koji se usuđuju da se drznu na njega i imaju drugačije mišljenje. Zbog toga zaključuje da je bog tiranin, odnosno demonsko božanstvo, a ne benevolentno stvorenje o kome govori Novi zavet. Lako se otkriva veza između Melvilovih duhovnih, intelektualnih i umetničkih uverenja, u kojima centralno mesto zauzima promišljeno i lukavo izvrgavanje podsmehu hrišćanske doktrine. Godine 1850. Melvil piše pismo Natanijelu Hotornu u kom proglašava svoju nezavisnost od boga: došao je do zaključka da je jedini uspešan način da se naruši neravnoteža između boga i čoveka taj da se, umesto Adama, bog okrivi za prvobitni greh, odnosno za donošenje smrtnosti na ovaj svet. Reči 
kapetana Ahava „Ego non te baptiso in nomine Patris et Filii et Spiritus Sancti - sed in nomine Diaboli”, reči su samog Melvila. ${ }^{1}$ Međutim, on je odlično znao da je tadašnja čitalačka publika veoma posvećena hrišćanskoj veri i da ne bi prihvatila nikakve otvorene izjave o malicioznim namerama božanstva u koje slepo veruje. Javno obznanjivanje nezavisnosti od toliko suverenog božanstva ne bi mu donelo ništa drugo do podsmeha hrišćanske čitalačke publike. Ipak, želeći da književno uobliči svoje prikrivene jeretičke misli, Melvil postepeno razvija kompleksan stilski i strukturni obrazac kojim će svoje delo zaštititi od lovaca na jeretike. Pažljivo bira priču koju želi da ispriča i način na koji je piše. Iako koristi jezik koji bi se mogao opisati kao sakralni, jer „kipi od znakova transcendentalnog” (SELBY 1998: 111), zapleti u romanu smišljeni su tako da živopisno predstave Melvilove antidogmatske poglede. Melvil gradi takvu strukturu teksta da, ma koliko da sumnja u postojeće verske obrasce, na kraju ih uvek hvali i poštuje, iako pažljivom čitaocu neće promaći njegov cinizam i neiskrenost. Zbog ovakvog „pretvaranja”, tekst obiluje sarkazmom, satirom i ironijom - doslovno čitanje teksta vodilo bi čitaoce u suprotnom pravcu od samog zapleta. Da bi svoju kritiku hrišćanskog tumačenja sveta sakrio od književne inkvizicije, Melvil je razvio mnoštvo narativnih sredstava za odbrambeno prikrivanje, izvrdavanje, obmanjivanje, nadmudrivanje i izvrgavanje podsmehu. U tom smislu, ne treba da nas čudi što je zajednička karakteristika svih ranih kritika romana bila zbunjenost neuobičajenim dvosmislenim komentarima autora, nejasnom žanrovskom opredeljenošću i nekonvencionalnim tumačenjem hrišćanskog morala (SELBY 1998: 22).

Melvil je naučio od književnih velikana kako da alegorijsko prikazivanje dovede do savršenstva. Matisen u obimnoj kritičkoj studiji Američka renesansa navodi četiri velika Melvilova književna izvora: Šekspira, engleske metafizičare XVII veka, Miltona i Hotorna. U ovom

\footnotetext{
1 Melvil u pismu Hotornu kaže: „Priča još nije skuvana, mada je razumno reći da je oganj pakla, na kom se cela knjiga krčka, već skuvao i priču. (Tajni) moto knjige je - Ego non baptiso te in nomine - možeš i sam da dopišeš ostalo." (Prevod M.D). N. Selby (ed.). 1998. Herman Melville - Moby-Dick. Cambridge: Icon Books Ltd., str. 23.
} 
radu bavićemo se intertekstualnošću poezije nekoliko engleskih metafizičara i Melvilovog romana Mobi Dik, na način da otkrivamo skrivene i manje skrivene veze između ideja metafizičkih pesnika i ideja koje iznose glavni junaci Melvilovog romana.

\section{INTERTEKSTUALNOST}

Pojam intertekstualnosti, verovatno najslikovitije, objasnila je Julija Kristeva, koja je tvrdila da pisci ne stvaraju književne tekstove zato što imaju maštovit i kreativan um, već ih skupljaju iz ranije napisanih tekstova. Na taj način, tekst postaje nova permutacija postojećih tekstova (Kristeva 1980: 36). Čak i da se ne složimo u potpunosti sa njenim polazištem, jasno je da svi književni tekstovi moraju pripadati jednoj kulturnoj, ili umetničkoj, celini. Mnogi raniji pisci imali su običaj da sami navedu svoje književne uzore u nadi da će im oni biti određena preporuka kod čitalaca. I savremeni autori često u intervjuima govore o intertekstualnim relacijama svojih dela. Tako je proučavaocima Melvilovog dela vrlo dobro poznato njegovo duboko prijateljstvo, privatno i književno, sa drugim američkim književnim velikanom - Natanijelom Hotornom. Gusto popunjene margine knjiga koje je Melvil držao u rukama, a koje se danas čuvaju u biblioteci Univerziteta u Prinstonu, svedoče o svojevrsnom „podstreku” koji je Melvil pronašao u delima Homera, Vergilija, Šekspira, Džona Miltona, kao i u Svetom pismu, a bez kog bi epski kvalitet Melvilovog stvaralaštva verovatno bio mnogo drugačiji. Zbog mnoštva književnih uticaja kojima je Melvil, u manjoj ili većoj meri, podlegao, tekst romana Mobi Dik predstavlja eklatantan primer intertekstualnog pisanja u smislu Ekove tvrdnje da je u književnosti „prošlost neizbežna” (Eko 1985).

Iako je pojam intertekstualnosti uveden u književnu teoriju šezdesetih godina XX veka u dinamičnoj interakciji nekoliko naučnih oblasti kao što su nauka o književnosti, filozofija, semiotika, logika (JuVAN 2013: 7), čini se da je još prisutniji u savremenim proučavanjima književnosti, pre svega zahvaljujući tome što je pogodan za sagleda- 
vanje uključenosti književnih dela u jedan širi - sociološki, kulturni, umetnički, jezički, politički - kontekst:

Intertekstualnost nas podseća da su svi tekstovi potencijalno pluralni, reverzibilni, otvoreni za pretpostavke čitalaca, jer nemaju jasno postavljene granice i podrazumevaju stalnu ekspresiju / represiju dijaloških glasova koji postoje u društvu. (AlLEN 2000: 209)

Intertekstualni pristup čitanju određenog dela podrazumeva da čitaoci budu u izvesnom smislu detektivi koji prate tragove u tekstu i tragaju za rešenjima kojima će otkloniti, ponekad radikalnu, polisemiju. Prisustvo jednog teksta u drugom, u intertekstualnom značenju, nije mimetičko, stoga je obavijeno implicitnim upućivanjima na književne interakcije. S jedne strane, intertekstualno čitanje može da otvori polemiku sa tradicijom, ali i započne modernu dijalošku komunikaciju sa savremenim tekstovima ili drugim umetničkim formama (JuvaN 2013: 21). Iako su u Mobi Diku najupadljivije reference na Sveto pismo, koje autoru služe da se „razračuna” sa bogom sa kojim ima nerazrešene račune, pažljivim čitanjem moguće je uspostaviti niz intertekstualnih veza i sa drugim izvorima. Nije teško pronaći začetke Melvilovih ideja kod engleskih metafizičara, samim tim što oni obilato koriste biblijske aluzije i alegorije. Pored stilskih sredstava, tokom osmišljavanja Ismailovog lika Melvil je razmišljao u okvirima metafizičke poezije - o slučaju, o slobodnoj volji, o nužnosti. Ismailove metafizičke meditacije o tajnama univerzuma ispunjene su odjecima poezije Džona Dona (John Donne), Džordža Herberta (George Herbert), Henrija Vona (Henry Vaughan). Najzad, tema lovca koji po cenu života neće odustati od hvatanja plena deluje pomalo viteški dok se lov ne pretvori u osvetnički pohod. Tada kapetan Ahav proglašava nezavisnost i oslobađa se hrišćanskih moralnih autoriteta, što u tekst unosi prizvuk metafizičkih stihova. 


\section{MetafiziČARI}

U istoriji engleske književnosti, metafizičarima smatramo neformalnu grupu pesnika koja je stvarala poeziju u kojoj otvoreno pokazuje svoju učenost, primenjujući određenu pseudologiku i koristeći grube, često paradoksalne metafore ili poređenja. Metafizičku poeziju često odlikuje neumitan strah od prolaznosti, kao i „muški” ton kojim se podvlači telesnost i seksualnost ljudske prirode. Njihovi stihovi sadrže govorni realizam i imaju usmeni kvalitet, koji se nije najbolje prihvatao u periodu u kom je vladala bogata, kićena lirika, stoga ne treba da čudi što se interesovanje za metafizičke pesnike probudilo tek početkom XX veka kada su određene Donove pesme uvrštene u antologije engleske poezije, odnosno nakon što je Tomas Sternz Eliot objavio esej „Metafizički pesnici”. U ovom eseju Eliot ističe da je veoma teško definisati metafizičku poeziju i „pronaći makar jednu jedinu preciznu upotrebu metafore, poređenja, ili drugih figura, koja bi bila zajednička svim pesnicima i u isti mah dovoljno značajna da kao element stila izdvoji ove pesnike u grupu" (ELiot 1963: 71). U tom smislu, metafizičari nisu sačinjavali školu, već bi ih trebalo nazivati pokretom, kako predlaže Eliot. Ipak, Eliot ističe končeto kao zajedničko sredstvo metafizičkih pesnika, kao postupak koji „ne prestaje da stapa disparatna iskustva” (EцIot 1963: 78), jer je duh takvog pesnika „besprekorno opremljen za svoj zadatak" (IBID).

Pojam metafizičari može biti zbunjujući, jer se ovi pesnici nisu bavili filozofskim pitanjima metafizike, nego su ih kritičari, pre svih Samjuel Džonson, okarakterisali kao pesnike koji se bave metafizičkim idejama, verovatno imajući na umu intelektualnu živost njihovih stihova nastalu upotrebom racionalističke logike. Dakle, opis „metafizička” poezija se primarno odnosi na stil, a u manjoj meri na sadržaj pesama. Ovaj pesnički manir odlikuju sažeti izrazi, često ostvareni uz pomoć eliptične sintakse. Osnivačem ove pesničke škole smatra se Džon Don, a njoj pripadaju i Endru Marvel (Andrew Marvell), Henri Von, Džordž Herbert, Ričard Krašo (Richard Crashaw) i Tomas Trahern (Thomas Traherne). Omiljeno književno sredstvo metafizičkih 
pesnika je končeto, koji bi se mogao opisati kao razrađena metafora kojom se udaljenim asocijacijama upoređuju dva, naizgled različita, predmeta ili osećanja, što kod čitalaca izaziva iznenađenje ili zaprepašćenje. Kod končeta su sličnosti zasnovane na logici, a ne na emociji. Uobičajena ilustracija metafizičkog končeta jeste Donovo poređenje ljubavnika sa dva kraka šestara u pesmi „Oproštajna reč: zabrana jadikovanja" (A Valediction: Forbidding Mourning):

Ako su dvoje, dvoje su oni tako

Kao što je nepomični kompas dvoje;

Tvoja duša, nepomična stopa, ne pokazuje

Da se kreće, ali to čini, ako to druga čini. (Don 1990: 84)

U ovom radu bavimo se sličnostima koje se mogu pronaći ne samo između određenih metafizičkih ideja i Melvilovih motiva u romanu Mobi Dik, nego i pristupom temi i njenom obradom.

\section{MELVIL I METAFIZIČARI}

Dosetljivost, visprenost, dovitljivost i domišljatost metafizičara bili su neophodni i Melvilu kako bi napisao jednu kompleksnu književnu parabolu prožetu agnosticizmom, čiju univerzalnu prirodu opisuju Ismailove reči: „Jer svi sumnjaju; mnogi poriču.” (MeLVIL 1954: 430) Teološka tematika kod metafizičkih pesnika često ima vid logičkog zaključivanja, vrlo zamršenog i protkanog naučnim pojmovima. Matisen ne vidi poetski cilj metafizičara u opisivanju misli, već uma u procesu razmišljanja (Mathiessen 1941: 130), što je uočljivo i u Melvilovoj prozi. Na primer, u romanu Mobi Dik u sceni u kojoj Ismail objašnjava mornaru i sadrugu Kvikvegu kako da postane tkač na delu je Melvilovo poigravanje hrišćanskom dogmom o predestinaciji:

Tu su ležali pričvršćeni konci od kanapa koji su bili podložni jednom jedinom podrhtavanju koje se jednako ponavlja i nikako ne menja, a to je podrhtavanje bilo sasvim dovoljno da dopusti ukršteno mešanje drugih konaca sa njihovim sopstvenim. Ovaj je konopac izgleda neka nužnost; 
i ovde, mislio sam ja, ja sam svojom sopstvenom rukom prionuo za svoj sopstveni čunak svoju sopstvenu sudbinu u ove neizmenjive konce. Za to vreme Kvikvegov leteći, neumoljivi mač, ponekad bi pogodio potku sa strane ili krivo, ili jako, ili slabo, kako se već desi; s tom razlikom u završnom udarcu stvarao je odgovarajuću promenu u krajnjem izgledu završenog posla. Mač ovog divljaka, mislio sam ja, koji tako završno daje oblik i izgled i kanapu i osnovi; ovaj okretni neumoljivi mač mora biti neki slučaj - zbilja, slučaj, slobodna volja, i nužnost - koji se pametno ne isključuju - svi se oni upliću jedan u drugi i rade zajedno. Pravi konopac nužnosti, koji ne može skrenuti sa svoga krajnjeg pravca - iako međutim svako uzastopno podrhtavanje samo tome teži; slobodna volja, zbilja, slobodna da protura svoj čunak između datih žica; a onda slučaj, mada je ograničen u svojoj igri između pravih linija nužnosti, a pobočnim putevima u njegovom kretanju upravlja slobodna volja - mada je tako propisano i od jednog i od drugog, slučaj s vremena na vreme upravlja i jednim i drugim i događajima zadaje poslednji udarac koji daje oblik. (Melvil 1954: 248-249)

U ovom deskriptivnom odlomku dominiraju metafore koje govore o međusobnom odnosu slučaja, slobodne volje i nužnosti i koje jasnije opisuju njihovu prožetost nego što bi stranice i stranice nekakve argumentacije. Melvil, kao i metafizičari, razmišlja u slikama. Kada bi odeljak imao poetsku formu, mogli bismo govoriti o Melvilovom metafizičkom končetu u kom on konce posmatra kao ljudske sudbine, a Kvikvegov mač kao slučaj koji će odlučiti o ishodu tih sudbina isključivo na osnovu Kvikvegove slobodne volje koja upravlja događajima. Ovom slikom Melvil želi da pokaže da se pojam slobodne volje ipak mora razumeti sa rezervom, jer je sloboda odlučivanja ograničena voljom onoga koji ima moć (mač). Dakle, primećujemo da je kod Melvila, kao i kod metafizičara, končeto nastao oštroumnim, neobičnim, čudnovatim i veoma detaljnim poređenjem, koje opisuje uglavnom duhovne kvalitete.

Kako je Melvil posedovao radoznalost jednog filozofa, brzo je postao očaran metafizičkom poezijom, koju je ugradio u celokupno književno stvaralaštvo (Mathiessen 1941: 130). S obzirom na upečatljivu biblijsku simboliku u romanu Mobi Dik, najveće sličnosti nalazimo između Melvila i onih metafizičara koji su se bavili teološkom tematikom - Džordža Herberta i Henrija Vona. Mnogi smatraju da je Vonova zbirka pesama Silex Scintillans (1650-1655) delo koje sadrži 
najviše biblijskih motiva u istoriji engleske poezije. Pesnik „posmatra” Tvorca kako stvara i uverava nas da čak i kada neke prirodne pojave ili stvorenja predstavljaju prepreke za čoveka, izazivaju ga i muče, kada su nerazumljive kao hijeroglifi i kada ih ne možemo protumačiti, one su ipak sveto pismo u nastajanju, naš jedini pristup „raju i svetlu” (Bradbury, Malcom \& Palmer 1970: 151). Brzo ćemo uočiti da Melvilov neustrašivi kapetan Ahav odlično zna ono što Von piše u svojoj poeziji - da je Tvorčeva volja nesporna. Ali, kao prkosni pobunjenik, on nema snage da se odupre unutrašnjem nagonu da lovi i progoni Mobi Dika - stvorenje božanske prirode, koje bi samim tim za njega trebalo da bude sveto. Međutim, kapetana pokreće osveta prema belom kitu koji mu je naneo uvredu koju ne može da zaboravi:

Mobi Dik je odneo moje jarbole; Mobi Dik me je doveo na ovaj mrtvački patrljak na kome evo sad stojim. Jeste, jeste, viknu on strašno, glasno, životinjsko jecanje. [...] to je bio taj prokleti Beli kit koji me je potsekao. I ja ću ga goniti oko Dobre nade i oko Horna i oko norveškog Maelstrema, i oko samog pakla, pre nego što dignem ruku na njega. (MelviL 1954: 190)

Kapetan Ahav mašta o tome da se osveti velikom belom kitu, koji je od njega napravio bogalja tako što mu je odgrizao nogu. Njegova odluka da bez uzmicanja progoni Mobi Dika predstavlja mnogo više od puke žudnje za osvetom. „Osveta pretvorena u cilj života dovodi u pitanje, ili otvoreno negira neke od osnovnih hrišćanskih principa" (PAUnović 2006: 176). Kako Ahavov lov, a potom i borba sa najvećim morskim bićem, dobija mitske dimenzije, rat koji kapetan vodi može se okarakterisati kao rat sa prirodom u najširem filozofskom, pa i metafizičkom smislu: taj rat se odvija u arhetipskim kategorijama praelemenata vode i zemlje, svetlosti i tame, dirljive ljubavi i bezumne mržnje (PAUNOVIĆ 2006: 177).

U svom poetskom stvaralaštvu Henri Von nam poručuje da mora postojati jasna granica između vere i poetske imaginacije. Ali, estetski i epistemološki, obe predstavljaju moć simbolike kojom daleko može postati blizu, odsutno može postati prisutno, a nevidljivo - vidljivo. Kako Von piše u svojim stihovima, samo dela pesničke imaginacije mogu zadovoljiti potrebe vere i ponuditi načine da se pronađe bog. 
Odnosno, pesnik i sveštenik moraju postati jedno. (Bradbury, Malcom \& PALMER 1970: 152) Imajući u vidu da je u elizabetinsko doba cilj pisanja poezije bilo traganje za istinom (Hammond 1974: 130), ne treba da čudi tolika upitanost metafizičkih pesnika o suštini života, ljubavi, vere, kao i pobuni protiv nametnutih hrišćanskih načela. Kod Melvila je uočljiva metafizička ideja da put ka raju mora ići preko pakla, jer su oni dve strane jedne celine. Poput Miltona, metafizičari vrlo jasno pokazuju da božja sveprisutnost mora obuhvatiti i pakao: da bi se pevalo o raju, potrebno je suočiti se sa paklom (Bradbury, MaLcom \& Palmer 1970: 162). Slično tome, Melvilov Ahav tvrdi da red ne postoji bez nereda, ali se trudi da pokaže da je ovaj prirodni dualizam nastao usled podmuklosti Tvorca. Zbunjen dijalektikom dobra i zla na zemlji, Von daje sebi slobodu da primeti da lepota poput nebeske treba da omogući isceljenje, a ne da produbi rane. ${ }^{2}$ Pesnik veruje da sve što je nebesko treba da ima terapeutsko dejstvo umesto da pospešuje bol i patnju. U njegovom stihu da kod boga postoji duboka, blješteća tama ${ }^{3}$ čujemo glas kapetana Ahava koji se obraća bogu: „Iako si svetlost, $i z$ mraka dolaziš, a ja sam mrak proizašao iz svjetlosti što od tebe dolazi." (Melville 1985: 470, kurziv MD) Ipak, autentičan i kao pesnik, i kao metafizičar, Henri Von smiruje kritički stav tako da se u svakoj pesmi pobuna okončava svojevrsnim spokojem koji pesnik postiže i prenosi na čitaoce. Pažljivim čitanjem primetićemo da u njegovoj poeziji bog nije „ljudsko otelotvorenje božanske ljubavi koja leži u svakom stihu jevanđelja” (Whiтe 1956: 301), već je „Život i svetlo cele vasione” (IBID), odnosno „božanska promisao kojoj čovek treba da se preda” (IBID). Promišljanje o božanskoj prirodi i upitanost nad opravdanošću božanskih zakona dovode Henrija Vona do zaključka da se istina nalazi u jedinstvu sa bogom nasuprot prevrtljivosti ovozemaljskog života (IBID). U tome leži suštinska razlika između metafizičara i Melvila - dok metafizički pesnici pišu poeziju da bi opravdali i objasnili čudesne načine

2 "Beauties like Heav'n, their Gifts should deal / Not to destroy us, but to heal." (Henry Vaughan, To Etesia parted from him, and looking back).

3 "There is in God (some say) / A deep, but dazzling darkness;" (Henry Vaughan, The Night). 
kojima bog deluje i stvara, Melvil želi da pokaže neopravdanost i čestu nerazumnost tih načina. Ipak, ako prihvatimo da intertekstualnost govori jezikom koji je nastao kao zbir svih postojećih tekstova (AlLEN 2000: 114), Melvilova odstupanja od stavova i zaključaka metafizičara ne bi podrazumevala da se on odriče metafizičkog uticaja, jer su intertekstualne veze između metafizičke poezije i Melvilovih ideja dovoljno upečatljive da se ne mogu poricati.

Džon Don u „Svetom sonetu broj 9” tvrdi da nije čovek kriv što je osuđen na smrtnost nego je drvo znanja bilo početak čovekovog kraja. Pesnik se otvoreno pita zašto bi ljudski rod bio kažnjen ako neka druga bića koja čine zlo ostaju nekažnjena. ${ }^{4}$ Tradicionalan odgovor da je čovek proklet zato što je jedino biće koje poseduje razum i, samim tim, sposobnost da promišlja ne zadovoljava pesnika, jer se sa razumom rađamo, razum je inherentna ljudska osobina, a ne samostalan izbor. On zaključuje da, shodno tome, krivica mora pasti na onoga koji je stvorio ljudski rod i podario mu razum. Za razliku od Ahava, čiji je osvetnički žar podgrejan srdžbom prema bogu, Don ipak sonet završava iskazujući strahopoštovanje prema svevišnjem koga moli da mu oprosti jeretičke misli. Međutim, Melvilov (anti)heroj bez trunke pokajanja ulazi u okršaj sa bogom, što je sasvim u skladu sa simbolikom biblijskog imena koje mu je pisac dao. Sveto pismo kapetanovog imenjaka opisuje rečima: „I činjaše Ahav sin Amrijev što je zlo pred Gospodom, više od svijeh koji bijahu prije njega." (Sveto pismo, Prva knjiga o carevima 16:30, 333). Dakle, biblijski Ahav bio je poznat po velikom zlu koje je činio, jer se usprotivio božjoj reči. Melvilov Ahav je prkosni pobunjenik, žedan osvete prema belom kitu i nepokolebljiv u nameri da kita goni oko samog pakla sve „dok kit ne ištrca crnu krv” (MelviL 1954: 602). Moglo bi se reći da Donova ideja pobune protiv neprikosnovenog božanskog autoriteta nastavlja da živi u liku buntovnog kapetana Ahava koji ne prestaje da kritikuje hrišćansku postavku sveta.

4 "If poisonous minerals, and if that tree, / Whose fruit threw death on (else immortal) us / If lecherous goats, if serpents envious / Cannot be damn'd, alas! Why should I be?" (John Donne, Holy Sonnet IX, available at: http:/www. luminarium.org/sevenlit/donne/holysonnet9.php) 
Dakle, „antihrišćansko” poetsko seme koje je Don posejao u XVII veku izniklo je u Melvilov pobunjenički roman u XIX veku. Intertekstualni dijalog koji postoji između dva autora, odnosno između njihovih ideja, potvrđuje tvrdnju da ne postoji značenjska stabilnost, kao ni objektivno tumačenje teksta, koju iznose poststrukturalisti govoreći o intertekstualnosti (ALLEN 2000: 3).

Identičan motiv pobune protiv neprikosnovenog hrišćanskog poretka nalazi se u pesmi „Okovratnik” Džordža Herberta, koju mnogi smatraju njegovom najboljom pesmom (HunTer 1968: 113). Govornik se hrabro i otvoreno buni protiv božanskog autoriteta: bog je predstavljen kao otac, a govornik želi da napusti očev dom. ${ }^{5}$ Na određeni način, cela pesma opisuje nered, a raspored rime je zamišljen tako da prenese haotičnu sliku: abcbadeadc. Dakle, i sama struktura pesme predstavlja ideju koju pesnik želi da prenese čitaocima. Odjek lupanja pesnicom o sto iz prvog stiha Herbertove pesme stiže do Melvilovog samostalnog, odlučnog, prkosnog i hrabrog kapetana Ahava. Junaštvo Herbertovog govornika, kao i kapetana koji juri belog kita oko celog sveta leži u tome što nijedan ne prihvata postojeći poredak, već obojica pokreću akciju, kreću u borbu za pravo samostalnog odlučivanja u skladu sa slobodnom voljom. Kod Herberta se, očekivano, u poslednjim stihovima tenzija spušta, ${ }^{6}$ dok Melvil svoje delo završava svojevrsnim pripovedačkim krešendom u kom kapetan Ahav, u konačnom okršaju sa svojim neprijateljem, gubi život. Ovaj narativni vrhunac ima za cilj da razotkrije alegoriju koja je prisutna od početka romana i da onim čitaocima, koji nisu prozreli da avanturistička priča obiluje biblijskom simbolikom, ukaže na buntovništvo koje je Melvil utkao u tekst.

Iako Tomas Eliot u studiji o Džordžu Herbertu tvrdi da ovog metafizičara ne možemo nikada optužiti za „pobožnu neiskrenost” (ELIoT 1994: 30), činjenica je da pesnik piše stihove u kojima „pada i ustaje” (IBID). Ipak, Herbert svoja razmišljanja i preispitivanja po pravilu zavr-

5 "I struck the board, and cried, No more. / I will abroad." (George Herbert, The Collar, HunTer 1968: 113).

6 "Methought I heard one calling, Child! / And I replied, My Lord." (George Herbert, The Collar, Hunter 1968: 114). 
šava izrazima zahvalnosti prema Svevišnjem i duhovnom smirenošću koja nastaje kada se zabludeli vrati u očevo krilo. ${ }^{7}$ U pesmi „Cvet” on govori o olakšanju i nestanku tuge koji su izazvani božjim blagoslovima, za razliku od osećanja uznemirenosti koje se javlja kada se živi van okrilja vere. U Herbertovim mislima nema strastvene revolucionarnosti kapetana Ahava, a svaka pesnikova sumnja u božanski poredak vodi ka duhovnoj smirenosti i priznanju da je potrebno da se predamo bogu. Najzad, u pesmi „Duhovi” Herbert boga opisuje kao neprestanu ljubav i svetlost. ${ }^{8}$ Dakle, možemo zaključiti da je Melvil preispitivanje božanskog autoriteta preuzeo od metafizičara, ali ga je razradio i produbio sumnjama u snagu slobodne volje („ma šta radio, ja rukujem samo jednim krajem konopca” (MeLVIL 1954: 370)) i oštrim verbalnim izlivima o uzvišenosti božanskog bića. Kada, na kraju romana Mobi Dik, dolazi do konačne bitke između kapetana i belog kita, odnosno kada beli kit prvi put izroni, čitaoci dobijaju ključ za tumačenje Melvilove narativne alegorije: „[... ] veliki bog se pokaza” (MeLviL 1954: 625). Ovim rečima avanturistička potraga za Mobi Dikom pretvara se u biblijsku priču o obračunu prkosnog Ahava sa bogom. Da je tekst napisan kao metafizička pesma, tenzija bi se verovatno spustila nakon prvog dana potere kada je Mobi Dik prevrnuo nekoliko čamaca uznemirivši članove posade. Ahav bi u dijalogu sa svevišnjim spoznao svoje grehe i prikupio duhovnu snagu da odustane od obračuna, te niko ne bi stradao već bi zavladalo osećanje duhovnog mira i olakšanja. No, kako se približavamo klimaksu, Ahav sve češće naglašava da jurnjava za belim kitom nije izbor njegove volje, već je nešto čemu se on ne može odupreti - neka sila tera ga da postane arhetipski lik u kosmičkoj borbi koja kao da traje od početka vremena. On priznaje da je glavni pokretač njegovih dela strast, a ne razum:

Ahav nikada ne misli; on samo oseća, oseća, oseća; to je dosta glavobolje za smrtna čoveka. Misliti, to je smelost. Samo Bog ima to pravo i to preimućstvo. Mišljenje

$\gamma$ "How fresh, O Lord, how sweet and clean / Are thy returns! ev'n as the flowers in spring;" (George Herbert, The Flower, ELIOT 1994: 30).

8 "Lord, though we change, thou art the same; / The same sweet God of love and light" (George Herbert, Whitsunday). 
je, ili bi bar trebalo da bude, hladnoća i mir; a naša jadna srca podrhtavaju i naši jadni mozgovi udaraju suviše jako za to. (MelviL 1954: 642)

S druge strane, zanimljivo je primetiti da pišući o Herbertovoj poetskoj genijalnosti, Eliot ističe da u njegovim stihovima preimućstvo imaju osećanja (EцIот 1994: 24). Upoređujući poeziju Dona i Herberta, kritičar naglašava da kod Dona „misao kontroliše osećanja” (ELiot 1994: 24) dok kod Herberta „osećanje kontroliše misli” (IBID). U navedenom odlomku, kod kapetana Ahava primetna je ova herbertovska crta da se odluke donose kao posledica osećanja, a ne razuma. Zbog toga kapetan izgleda kao romantičarski pobunjenik bajronovskog ili šelijevskog tipa, ali u njegovoj neprekidnoj upitanosti nad opravdanošću božanske promisli odzvanjaju glasovi metafizičara koji se često bave odnosom mikrokosmosa običnog čoveka i hrišćanskog makrokosmosa.

Intertekstualno čitanje Melvilovog romana i stihova metafizičara od čitaoca stvara aktivnog tumača, svojevrsnog književnog detektiva koji će pronalaziti tragove metafizičke poezije u tekstu koji je napisan u XIX veku. Imajući u vidu da intertekstualna dimenzija ne znači da je jedan tekst mimeza drugog, već da je čitanje jednog obogatilo stvaranje drugog teksta, uticaj metafizičke poezije na pisanje romana Mobi Dik može se opisati rečima Julije Kristeve da se „iskazi preuzeti iz drugih tekstova ukrštaju i neutrališu jedan drugog" (ALLEN 2000: 35). Iako Melvil i metafizičari iznose slične dileme i sumnje, koje se u njihovom stvaralaštvu „ukrštaju”, one se međusobno značenjski neutrališu, jer, kakvu god da izvučemo pouku iz Melvilovog romana, ona se neće podudarati sa porukama koje nalazimo na kraju Vonovih, Herbertovih i Donovih pesama.

\section{ZAKLJUČAK}

Kada Kristeva pojašnjava pojam intertekstualnosti, ona insistira na tome da intertekstualnost nije puko preuzimanje ideja i reči iz izvora i ne podrazumeva isključivo uticaj jednog teksta na drugi, već 
da jedan tekst sadrži primetne odjeke jezika i diskursa nekih drugih tekstova (ALLEN 2000: 36). Samim tim, možemo reći da je svaki književni tekst inherentno polifon, jer se u njemu mešaju zvuci ranije napisanih književnih dela. Poezija, kao i misao XVII veka, posle perioda srednjovekovnog nekritičkog obožavanja svevišnjeg, otkriva i priznaje dualistički svet u kom čin umiranja može biti čin ponovnog rađanja, jer je smrt deo života, a Hristovo koplje je istovremeno blagorodno i ubojito. Upravo metafizički pesnici poetski otkrivaju dualizam Hristove prirode. Kada se Džon Don na početku „Svetog soneta broj 9” obraća sam sebi, kao da ga bog ne može čuti, i kaže da nije ljudski rod kriv što je osuđen na smrtnost, on među prvima u istoriji engleske poezije počinje da preispituje verske dogme. Njegovu upitanost o opravdanosti božjeg gneva brzo su prihvatili ostali metafizički pesnici i time zapalili pobunjenički fitilj u istoriji anglo-američke književnosti. Preuzevši od metafizičara ne samo razmišljanje o osnovanosti božje srdžbe i strogoće prema ljudskom rodu, već i visprenu misao, Melvil ispreda priču u kojoj je svoje hrišćanske nedoumice, kao i revolt nastao usled osećanja svevišnje nepravde, umotao u plašt biblijske alegorije, čime je zadovoljio očekivanja tadašnjeg prosečnog čitaoca, hrišćanskog vernika. S druge strane, veštim čitaocima, koji umeju da tragaju za značenjima ispod površine teksta, neće promaći piščeva oštra kritika i duboka razočaranost nebeskim i zemaljskim poretkom. Nije teško uvideti da i metafizičari i Melvil, manje ili više dosledno, pišu jezikom intertekstualnosti, koji Kristeva opisuje kao podrivački i revolucionaran (Alden 2000: 45). Naime, prema rečima Kristeve, značenje teksta je dvostruko: tekst ima svoje značenje koje izražava rečima, ali i značenje „istorijskog i društvenog teksta” (IBID: 37). Dakle, u tekst su, u određenoj meri, ugrađena postojeća društvena značenja - politička, verska, istorijska itd. S druge strane, intertekstualnost ne podrazumeva da jedan tekst predstavlja kompilaciju prethodno napisanih tekstova, već govori o stvaranju pod namernim, ali ponekad i nesvesnim, uticajem književnih prethodnika. Prihvatanje ovih uticaja nije puko oponašanje, već se oni „oblikuju u Melvilovom sopstvenom kalupu” (Mathiessen 1941: 432). Dijalog koji se odvija između Šekspira, 
Miltona, metafizičkih pesnika, Bajrona, Blejka, Šelija, Hotorna sa jedne i Melvila sa druge strane čini nam se stoga neizbežan i neprestan.

\section{Citirana LITERATURA}

ALLEN, Graham. Intertextuality. London \& New York: Routledge, 2000.

Bradbury, Malcom \& Palmer (eds.). Metaphysical Poetry. London: Edward Arnold Ltd., 1970.

DANIČÍć, M. „Biblijska simbolika u romanima Mobi Dik Hermana Melvila i Gospodar muva Vilijama Goldinga”. Filološki fakultet u Beogradu. Neobjavljen magistarski rad. 2005.

Don, Dž. Predavanje o senci, prev. Dušan Puvačić. Banja Luka: Glas, 1990.

Drabble, M. (ed.). The Oxford Companion to English Literature. Oxford: OUP, 1994.

Eко, Umberto. Napomene uz Ime ruže. 1985. [Internet] Dostupno na: https:// hiperboreja.blogspot.rs/2014/09/napomene-uz-ime-ruze-umbertoeko.html [5.12.2017]

Euiot, T.S. George Herbert. Plymouth: Northcote House Publishers Ltd, 1994.

ELiot, T.S. Izabrani tekstovi. Beograd: Prosveta, 1963.

Hammond, G. (ed.) The Metaphysical Poets. London: The Mamillan Press Ltd, 1974.

Hunter, J. The Metaphysical Poets. London: Evans Brother Limited, 1968.

Juvan, M. Intertekstualnost, prev. Bojana Stojanović Pantović. Novi Sad: Akademska knjiga, 2013.

Kristeva, J. Desire in Language: a Semiotic Approach to Literature and Art. New York: Columbia UP, 1980.

Mathiessen, F.O. American Renaissance. New York: Oxford UP, 1941.

MeLvil, H. Mobi Dik. Beograd: IP Rad, 1954.

Melville, H. Moby Dick. Zagreb: Sveučilišna naklada Liber, 1985.

Paunović, Z. „Mobi Dik: Ep o neuhvatljivom”. Istorija, fikcija, mit. Beograd: Geopoetika, 2006, 175-179.

Selby, N. (ed.). Herman Melville - Moby-Dick. Cambridge: Icon Books Ltd., 1998.

Sveto pismo Staroga i Novoga Zavjeta, prev. Đ. Daničić i V. Stefanović Karadžić, Beograd: Britansko i inostrano biblijsko društvo.

Whiтe, H. The Metaphysical Poets - A Study in Religious Experience. New York: The Macmillan Company, 1956. 
Mirjana Daničić

\title{
OVERTONES OF METAPHYSICAL POETRY IN HERMAN MELLVILLE'S MOBI DICK
}

\author{
Sum mary
}

This paper investigates into the similarities between the $17^{\text {th }}$ century English metaphysical poetry and Herman Melville's novel Moby-Dick, primarily through the theory of intertextual reading and Julia Kristeva's idea that works of literature are filled with pluralism of meanings caused by their unavoidable and incessant dialogue. The author states that wittiness, shrewdness and perspicaciousness of the literary expression are shared characteristics of the metaphysical poetry and Melville's narrative about captain Ahab, the rebellious avenger, who uncompromisingly sails around the world to hunt the white whale - his biggest enemy on the planet. Besides the common motifs, similar literary devices can be recognized such as biblical allusions and allegories. The intertwining of motifs, stylistic devices, and philosophical and literary ideas underline the intertextual relations between the metaphysical verses and Melville's poetics.

Keywords: Herman Melville, Moby Dick, intertextuality, metaphysical poetry, conceit.

Univerzitet u Beogradu

Filološki fakultet

mirjanadanicic@gmail.com 